\title{
Cartografia e diplomacia: usos geopolíticos da informação toponímica (1750-1850)
}

\begin{abstract}
Iris Kantor ${ }^{1}$
RESUMO: $\bigcirc$ artigo explora dimensões geopolíticas da toponímia, registradas em documentos cartográficos, desde as reformas empreendidas pelo consulado pombalino em meados do século XVIII, até às primeiras décadas do século XIX, em meio ao processo de afirmação do Estado imperial pós-colonial.

PALAVRAS-CHAVE: Cartografia. Fronteiras. Toponímia. Impérios. Soberania, Legislação indigenista.

ABSTRACT: This paper explores the geopolitical dimensions of toponymy as registered in cartographic documents dating from the reforms pushed through by the consulate of Marquis of Pombal in the mid $18^{\text {th }}$ century to the early decades of the $19^{\text {th }}$ century, as the post-colonial imperial State established itself.

KEYWORDS: Cartography. Borders. Toponymy. Empires. Sovereignty. Indianist legislation
\end{abstract}

Os estudos do 2. Visconde de Santarém chamaram minha atenção para o uso geopolítico da toponímia na defesa das possessões ultramarinas. Exilado em Paris, o diplomata português advogou o uso de cartas geográficas preparadas por cartógrafos de diferentes nacionalidades para comprovar os direitos históricos dos portugueses na costa ocidental africana ${ }^{2}$. Em seus levantamentos, chegou a identificar mais de 130 topônimos portugueses registrados na cartografia quinhentista. Observava, porém, que a partir de meados do século $X V I I$ - com a fim da hegemonia hispânica e a ascensão das novas potências marítimas - houve um progressivo desaparecimento dos topônimos lusos nos mapas impressos difundidos pelas nações rivais, especialmente nos holandeses e franceses. Em sua opinião, a origem lusa dos topônimos deveria valer como argumento jurídico na disputa entre Portugal e França pelos territórios africanos de Casamansa (cabo de Santa Maria) em $1841^{3}$.

O diplomata fora incumbido de contestar a tese - proposta em 1832,

\begin{abstract}
1. Docente do Departamento de História da Faculdade de Filosofia, Letras e Ciências Humanas da Universidade de São Paulo. E-mail: <ikantor@ usp.br>. A autora agradece o apoio dos projetos temáticos Dimensões do Império Português (FAPESP) e do grupo de pesquisa Cia. das Índias da Universidade Federal Fluminense (Pronex CNPq).

2. Cf. $2^{\circ}$ Visconde de Santarém (1958, p. 84).

3. Cf. Martim de Albuquerque (1989, p. 7).
\end{abstract}


4. Cf. João Carlos Garcia (2006, p.15).

5. Cf. Claude Nicolet (1988, p. 5-25).

6. Ver Daniel Nordman (2000).

7. Cf. Patricia Seed (1999, p. 219-235).

8. Cf. Hugo Grotius, (2004, p. 339-281); Heloisa Meireles Gesteira, (2002); Anthony Padgen (2000); e, ainda, Antonio Manuel Hespanha (2004).

9. Cf. Sergio Buarque de Holanda. (1985), p. 310. por Lovis Estancelin ${ }^{4}$ - de que os normandos teriam sido os primeiros descobridores europeus naquela região. Os topônimos portugueses serviriam para provar a precedência dos portugueses na fundação de feitorias comerciais e fortalezas militares na costa ocidental da África. Ainda segundo sua argumentação, a posse e aquisição desses domínios teriam sido ratificadas por meio de tratados e convenções com os reis das nações africanas. De toda forma, para os propósitos deste artigo, importa reter a dimensão jurídica e diplomática evocada pelo uso dos topônimos nas negociações diplomáticas internacionais desde meados do século XVII.

Desde a antiguidade, os cerimoniais de posse incluíam o estabelecimento de uma nova toponímia a cada nova conquista 5 . Igualmente no Novo Mundo, os conquistadores e as coroas outorgavam-se 0 direito de nomear as terras descobertas, invocando o principio romano da res nullius: terras não ocupadas não constituíam direito de propriedade, assim como novos territórios ou ithas deviam pertencer aos seus primeiros ocupantes. Após a Paz de Westália (1648) - que pôs fim a Guerra dos Trinta Anos e garantiu a Independência das Províncias Unidas -, as reivindicações de posse de novas regiões passaram cada vez mais a exigir a apresentação de descrições geográficas e documentação cartográficab. Nesse aspecto, os mais hábeis em fixar topônimos nos mapas impressos teriam sido os holandeses, com a finalidade de manifestar a posse de um novo domínio ${ }^{7}$.

Em 1609, o jurista Hugo Groutius (597-1645), a serviço da Companhia das Índias Orientais, lança um manifesto contra o monopólio da navegação marítima (Mare liberum) em que propunha uma revisão dos critérios de titularidade das terras recém-descobertas pelos navegadores ${ }^{8}$. Para Grotius, o direito natural estava acima dos títulos de descoberta, ocupação, prescrição e doação pontifícia. Negando esta última, invalidava também a partilha estabelecida pelo Tratado de Tordesilhas (1494) e todas as outras concessões territoriais feitas pela Santa Sé às coroas ibéricas. Também se opunha ao valor jurídico dos padrões portugueses ou das cruzes de madeira colocadas pelos espanhóis em pontos estratégicos nas rotas de navegação e nas costas, tal como esta representada no mapa do engenheiro militar Andre Vaz Figueira, de 1754 (Figura 1). Segundo o jurista, a soberania só poderia ser exercida com a ocupação efetiva do território?.

Mas, apesar dos questionamentos suscitados pelo advogado da Companhia das Índias, os mapas impressos (e as evidências toponímicas) tornaram-se um recurso jurídico na afirmação das pretensões territoriais dos impérios marítimos, em franca concorrência. Foi justamente a partir da segunda metade do século XVII que a reivindicação de posse com base na nomeação dos territórios passou a ser invocada com maior frequência nos tribunais europeus. Portanto, quais teriam sido os modelos culturais que orientaram a atribuição dos topônimos luso-americanos nos registros textuais e cartográficos? Como fazer a análise dos múltiplos estratos toponímicos fixados em diferentes momentos? 


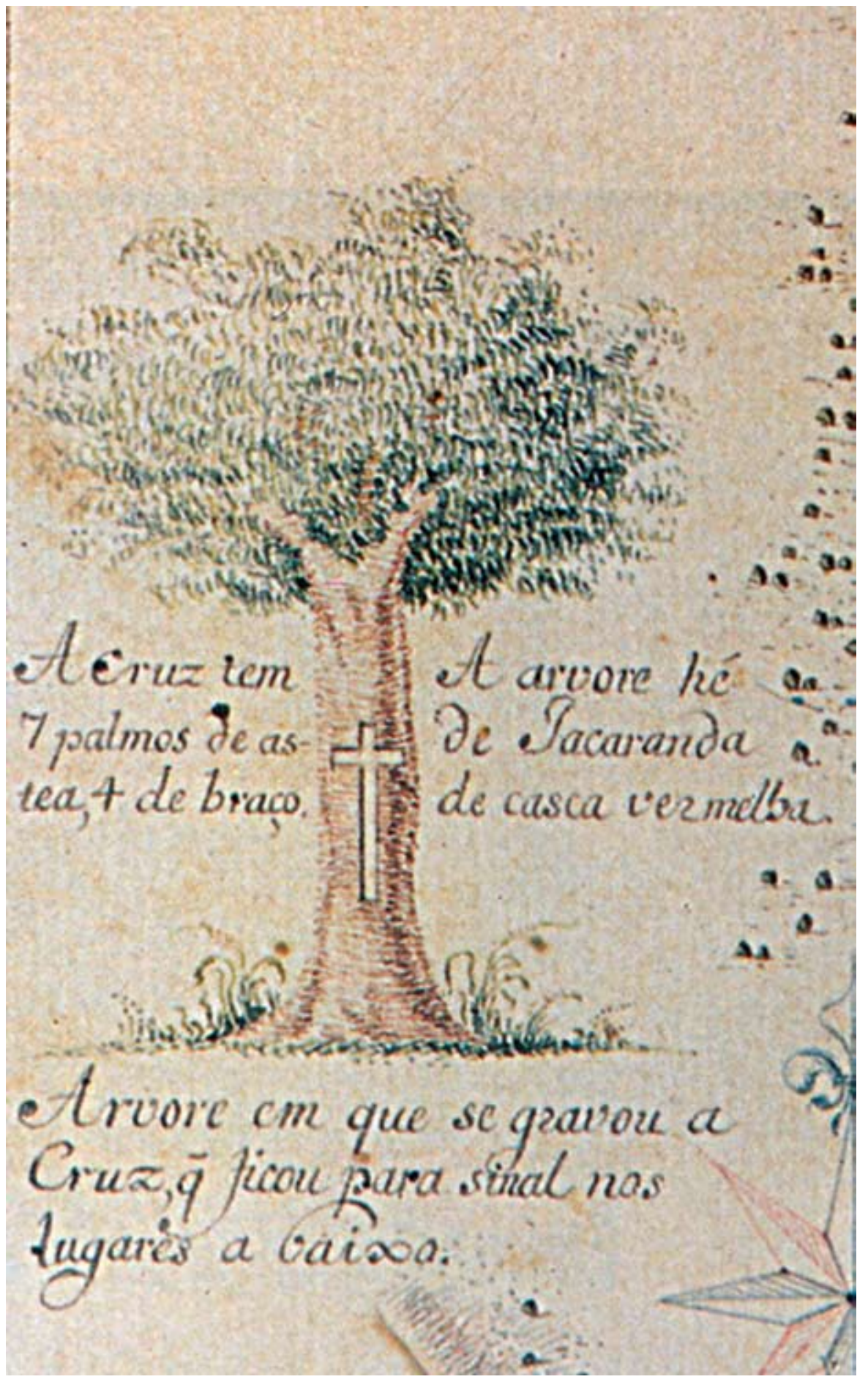

Figura 1 - Andre Vaz Figueira. Detalhe do Plano do Salto Grande do rio Paraná e desenho da árvore em que foi entalhada a cruz. 1754. Acervo da Mapoteca do Itamaraty, Rio de Janeiro. Fonte: ADONIAS, 1993, 289. 
10. Idem, ibidem.

11. Cf. Patricia Seed (1999, p. 235).

12. "The Spaniards and the English in fact seem to have adopted much the same approach to the renaming of American places." Cf. John Elliot (2006 p. 33).

13. Ver Renato Cimbalista (2006).

14. Ver Maria Vicentina de Paula do Amaral Dick (1990, p. 310-350).
Alguns estudiosos apontam que, nos séculos XV e XVII, os navegadores portugueses não tiveram preocupação explicita em estabelecer marcos toponímicos - como parece, entretanto, ter sido o caso dos holandeses ou mesmo dos espanhóis. Embora não descarte as possíveis evocações ao direito romano na toponímia ultramarina, Sérgio Buarque de Holanda considerava que, nos primeiros cento e cinquenta anos de colonização do Brasil, a designação dos topônimos fez-se de maneira fortuita, quase arbitraria, moldada, inclusive, por reminiscências da literatura de cavalaria medieval ${ }^{10}$. Por outro lado, Patrícia Seed sugeriu que os portugueses davam nomes de mercadorias negociadas numa determinada área: Costa do Ouro, Costa do Marfim, Costa da Malagueta, Brasil (pau-brasil); e, portanto, não teria ocorrido uma imposição de nomes a lugares estrangeiros ${ }^{11}$.

Segundo John Elliot, a atitude inicial dos conquistadores espanhóis e ingleses teria sido a mesma: ambos transliteravam os nomes nativos. No entanto, com o progressivo enraizamento das estruturas coloniais de governo, os monarcas foram exigindo a adoção da toponímia metropolitana ${ }^{12}$. Entre os colonos ingleses e espanhóis, de maneira geral, prevaleceu o costume de atribuir o nome da terra natal à nova pátria americana. Todavia, entre os ibéricos, a homenagem a santos e mártires cristãos era uma pratica comum, associando o calendário hagiográfico com as datas das "descobertas" ou da realização da primeira missa. A concessão do Padroado Régio - direito régio de controlar os rendimentos eclesiásticos e de promover a cristianização do Novo Mundo - fez com que as coroas ibéricas estimulassem a memória dos santos e mártires católicos. Com efeito, também os protestantes recorriam à onomástica sagrada, extraída do Velho Testamento, para imprimir impulso à cristianização do Novo Mundo.

Dado que, na Ásia e na África, o contato com a Europa datava de milênios, nessas regiões a toponímia atribuída pelos europeus foi resultado de formas mais complexas de apropriação da toponímia pré-existente. No continente americano, pelo contrário, os conquistadores e as coroas puderam exercer toda sua criatividade toponímica para reconfigurar o repertório cristão. As representações geográficas do continente americano apresentam-se como um repositório da memória da cristandade latina, na qual se fixaram os principais sucessos e eventos do hagiológio e do martirológio católico. A missão de conversão das almas e a apropriação do espaço materializavam-se por intermédio da designação dos lugares associada a nomes de santos e mártires. Por sua intermediação, as novas povoações passavam a integrar o corpo místico da cristandade ${ }^{13}$. A hagiotoponímia permitiu, ao mesmo tempo, a universalização e a particularização do empreendimento expansionista. Acidentes geográficos, aldeamentos missionários e vilas coloniais apresentam as mais diversas composições entre a onomástica sacra e as línguas indígenas nativas ${ }^{14}$. Veja-se os casos de: São Paulo de Piratininga (SP); Itacurussá (RJ), corruptela tupinizada da palavra cruz (curuçá + ita); Santo Antônio do Içá (AM); São Francisco de Arumã (AM), São Pedro do Jequitinhonha (MG), Santa Rita do Sapucaí (MG). A hibridização dos topônimos 
expressa as conexões entre localismo e universalismo católico na era da expansão marítima européia.

Após a atribuição dos topônimos litorâneos, fixados pelas expedições de reconhecimento costeiro nas primeiras décadas do século XVI, deu-se o processo de interiorização da colonização portuguesa, levado a cabo por sertanistas e por missionários. Esses, por sua vez, estimularam a adoção de termos tupis e guaranis para designar os acidentes geográficos ${ }^{15}$. Dessa conjugação entre o sistema de referência geográfico nativo e o impulso evangélico, multiplicaram-se as invocações a São Paulo, o Apóstolo dos Gentios, e às devoções às Nossas Senhoras até hoje presentes na toponímia brasileira, como mostra, entre inúmeras outras, a carta "Capitania dos Ilheos" de João Teixeira Albernaz I (Figura 2).

Sob o impacto da Paz de Utrecht (1713) - que praticamente invalidou o Tratado de Tordesilhas -, as coroas ibéricas iniciaram o mapeamento sistemático dos seus domínios territoriais na América do Sul16. Novos recursos foram investidos na formação de engenheiros militares, no patrocínio de expedições e na confecção de cartas e descrições geográficas in loco $^{17}$. Nas primeiras décadas do século
15. Ver Teodoro Sampaio (1987).

16. Ver André Ferrand de Almeida (2001, p. 47-73).

17. Ver Horacio Capel (1988); José Omar Moncada Maya (1993); e, ainda, Beatriz Bueno, (2001, cap. 5).

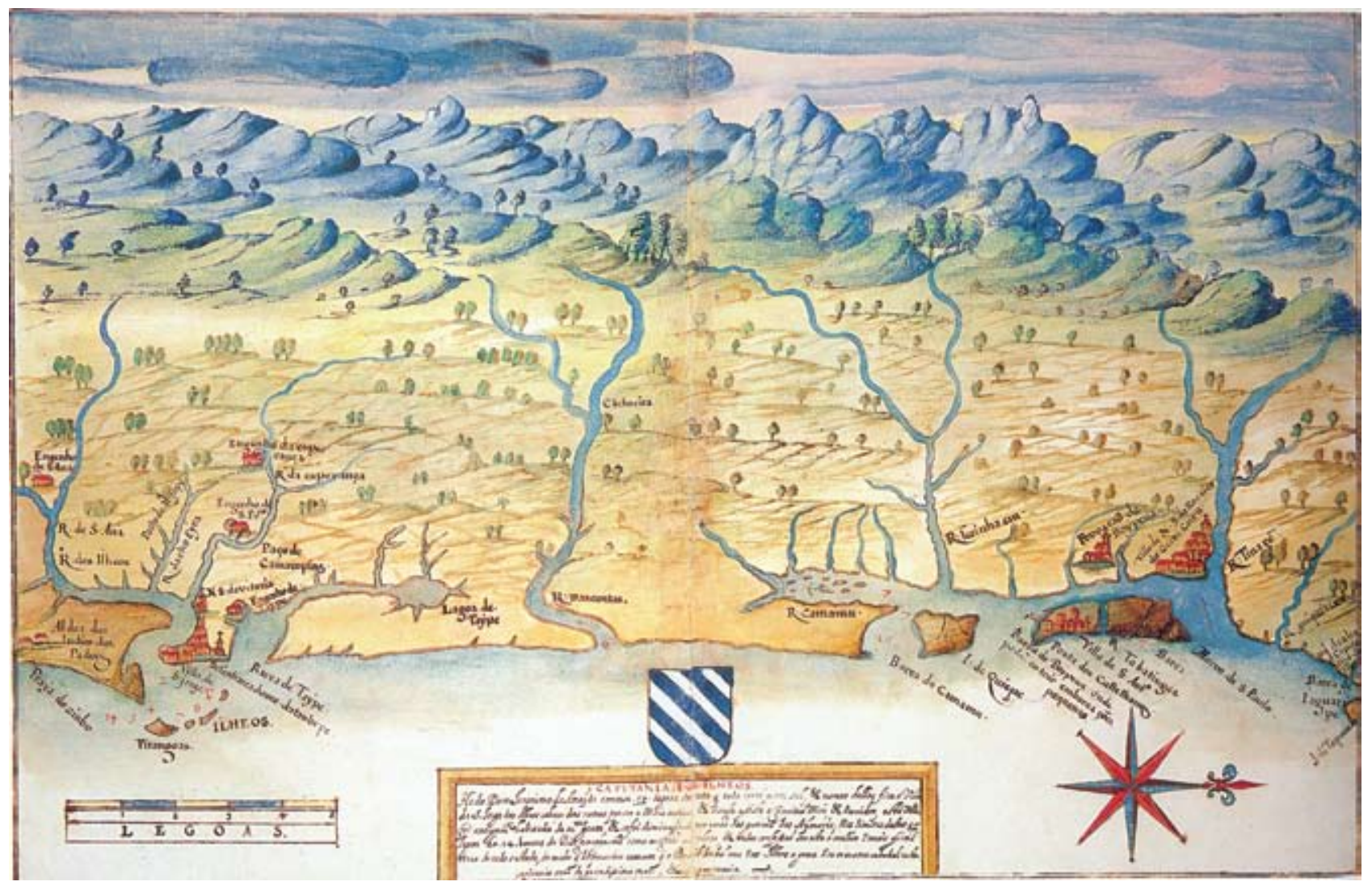

Figura 2 - João Teixeira Albernaz I. Capitania dos Ilheos. Estado do Brasil Coligido das. mais: sertas notícias q pode aivntar, Dõ Jerônimo de Ataíde. Por João Teixeira Albernas, Cosmographo de Sva Magde. Anno: 1631 . 1631 . Mapoteca do Itamaraty, Rio de Janeiro. Fonte: ADONIAS, 1993: 196. 
18. Cf. Íris Kantor (2004, p. 45-56).

19. Cf. Jaime Cortesão (1984, p. 319-394).

20. Cf. Neil Safier (2008, p 57-92).

21. Cf. A artigo VI do Tratado de Madrid. Cf. Jaime Cortesão (1984, p. 367; 369). Grifo meu.

22. Vejam-se os artigos VI e XI do Tratado de Madrid. Idem, ibidem.
$X V I I I$, diplomatas europeus estavam elaborando novos princípios de apropriação jurídica dos territórios ultramarinos. E, para municiar os diplomatas nas negociações internacionais, frequentemente eram convocados historiadores da Academia Real de História Portuguesa - criada por D. João V, em 1720 -, que desse modo, deu alguma atenção à preocupação com a defesa do patrimônio ultramarino ${ }^{18}$.

A Academia Real passou a solicitar às autoridades coloniais e aos colonos o envio de descrições geográficas, memórias históricas e documentação comprobatória da ocupação efetiva de todos os domínios lusitanos. Parte dessa documentação, colhida in loco, serviu, posteriormente, à preparação do Mapa das Cortes (1749), encomendado por Alexandre de Gusmão para as negociações com a Espanha em 1748-174919. A assinatura do Tratado de Madrid (1750) marca uma inflexão importante no tratamento dessas questões. Desde então, além do estabelecimento da fronteira "natural" (rios e picos das serras), os demarcadores procuraram fixar uma toponímia que traduzisse o processo de ocupação efetiva do território. $\bigcirc$ nome das povoações e aldeamentos missionários passou a ser um elemento-chave na definição das fronteiras entre os impérios ibéricos.

Os demarcadores e os governadores foram instruídos a renomear os acidentes geográficos, as vilas e os aldeamentos jesuíticos de origem espanhola encontrados em seus percursos. Visavam a erradicar a toponímia missionária para fixar o uti possidetis lusitano. Paradoxalmente, a despeito do esforço desprendido na lusitanização toponímica, a difusão dos relatos e mapas jesuíticos nas casas editoriais francesas, inglesas e italianas terminou por preservar, até praticamente meados do século XIX, o uso da toponímia jesuítica na cartografia impressa estrangeira. Não raro, as principais fontes de cartógrafos como Jean-Baptiste Bourguignon d'Anville (Figura 3) eram os mapas e crônicas dos jesuítas, amplamente divulgados na Europa das Luzes ${ }^{20}$.

Na época da assinatura do Tratado de Madri (1750), eram enormes as incertezas a respeito do uso dos topônimos de acidentes geográficos e localidades no Mapa das Cortes (1749). O próprio texto do Tratado admitia a fluidez da nomenclatura, especialmente, na região entre o rio lgureí e o rio Corrientes: "e, dali buscará em linha reta pelo mais alto do terreno a cabeceira principal do rio mais vizinho, que deságua no Paraguai pela sua margem oriental, que talvez será o que chamam Corrientes" 21 (Figura 4).

A dificuldade era tanta que os demarcadores eram orientados a confeccionar mapas individuais e estabelecer os nomes dos lugares em comum acordo com os comissários de ambas as coroas. Recomendava-se que as cópias fossem autenticadas in loco pelos comissários portugueses e espanhóis: "para que se não ofereça a mais leve dúvida, os referidos comissários porão nome de comum acordo aos rios, montes, que o não tiverem, e assinalarão tudo no Mapa com a individualização possível"22.

Não por acaso, Antônio Nunes Ribeiro Sanches (1699-1783) pronunciou-se sobre o Tratado de Santo Ildefonso firmado com a Espanha em 1 de outubro de 1777, advertindo que "muitos nomes de rios e de lugares, que se lêm no dito Tratado, não se acham na Carta de Mr. D'Anville, e pelo contrário; 


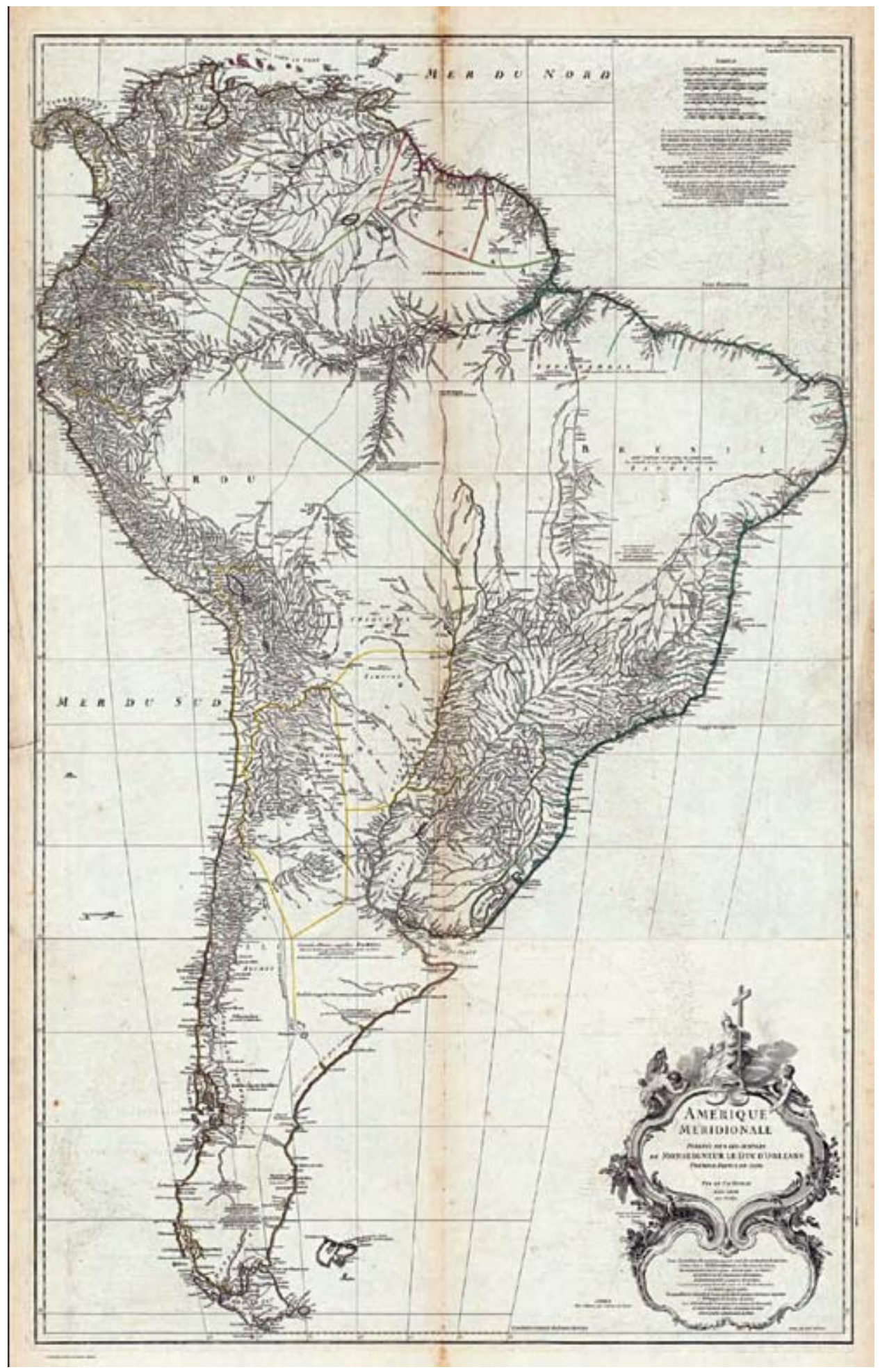

Figura 3 - Mapa de Jean-Baptiste B. D'Anville. Amerique Meridionale. 1748. David Rumsey Collection, Paris. 


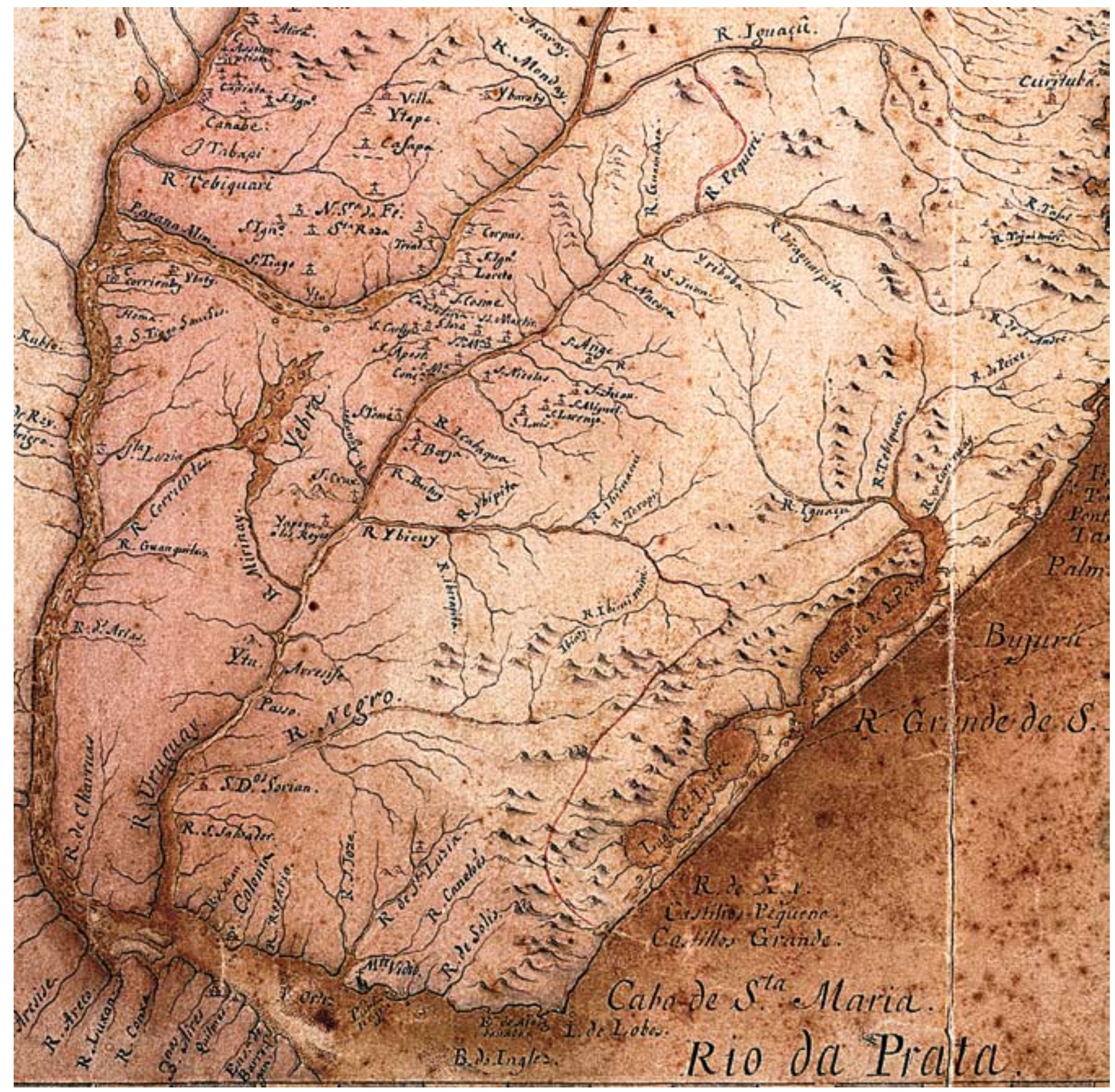

Figura 4 - Detalhe do Mapa das Cortes. 1749. Fundação Biblioteca Nacional, Rio de Janeiro. 
ou porque são escritos por um estrangeiro, ou porque este geógrafo não teve deles conhecimento" 23 . O reconhecido médico português procurava alertar os negociadores portugueses para que não usassem as cartas do famoso geógrafo francês Jean Baptiste Bourguignon d'Anville (1697-1782) e para necessidade de contratar cartógrafos nacionais, e não estrangeiros para fazer a demarcação dos limites.

Discrepâncias ou discordâncias na designação dos rios e arroios poderiam ter consequências na identificação exata da fronteira natural e humana. Na carta topográfica dos afluentes do rio Uruguai concluída em 1788, preparada pelos demarcadores Jose Varela y Ulloa e Sebastião da Veiga Cabral, encontra-se uma nota que justifica o desacordo entre os dois comissários, os quais, por sua vez, pediam que a solução fosse encaminhada no âmbito de um novo tratado entre as cortes ibéricas. No caso, os cartógrafos demarcadores indicaram no próprio mapa (Figuras 5-6) as suas controvérsias:

não estão conformes os nomes de alguns rios e arroyos que correm pelos terrenos que se reconheceram desde a Barra do Arroyo Chuy até a entrada do rio Pepiriguaçu no Uruguai; por cujo motivo desejando os dois respectivos comissários evitar confusão que disto se pode seguir, quando se tratar nas Cortes de estabelecer definitivamente os limites, acordarão também expressar reciprocamente nos mesmos planos estas diferenças ${ }^{24}$.

O detalhe do rio Pipiriguaçu da Carta Geral do Brasil, atribuída a José Joaquim Freire, 1797, também elucida sobre este tipo de querela (Figura 7).

Quais seriam os significados subjacentes à transformação da paisagem toponímica no contexto do Tratado de Madri e os tratados subseqüentes? Nessa perspectiva, parece-me que a erradicação da toponímia missionária e a renomeação dos lugares e acidentes geográficos foi parte de uma política mais ampla de afirmação da soberania interna e externa da coroa portuguesa no continente americano. Política concretizada por uma série de reformas administrativas, que, inclusive, levaram à expulsão dos jesuítas e ao confisco de seus patrimônios (1759), à transferência da capital da Bahia para o Rio de Janeiro (1763), e, principalmente, a uma nova política indigenista (1755-1758).

Entretanto, a afirmação da soberania exigia a expansão da rede administrativa, tanto civil como eclesiástica, em regiões ainda de fraca presença estatal. No campo militar, investia-se na construção de fortalezas, na reorganização dos regimentos militares e, sobretudo, no assentamento urbano das populações pobres e indígenas, por meio da instituição de um novo regime de trabalho compulsório nos aldeamentos. A partir de 1758, uma nova legislação pretendeu transformar o indígena em vassalo, útil ao pagamento do dízimo, à composição das tropas militares e à ocupação das fronteiras litigiosas ${ }^{25}$ (Figuras 8-9).

As aldeias missionárias foram transformadas em povoações civis. Criou-se, em cada uma delas, um Senado da Câmara, com juízes e vereadores indígenas. Além disso, o Rei concedeu uma sesmaria para cada vila. O Diretório
23. Cf. Reparos ao Tratado de Paz, 1777, em Antonio Nunes Ribeiro Sanches (1980, p.138).

24. Plano Topográfico, 17841788. Biblioteca do Congresso, Washington (D.C).

25. Ver Ângela Domingues (2000, p. 63-131). 


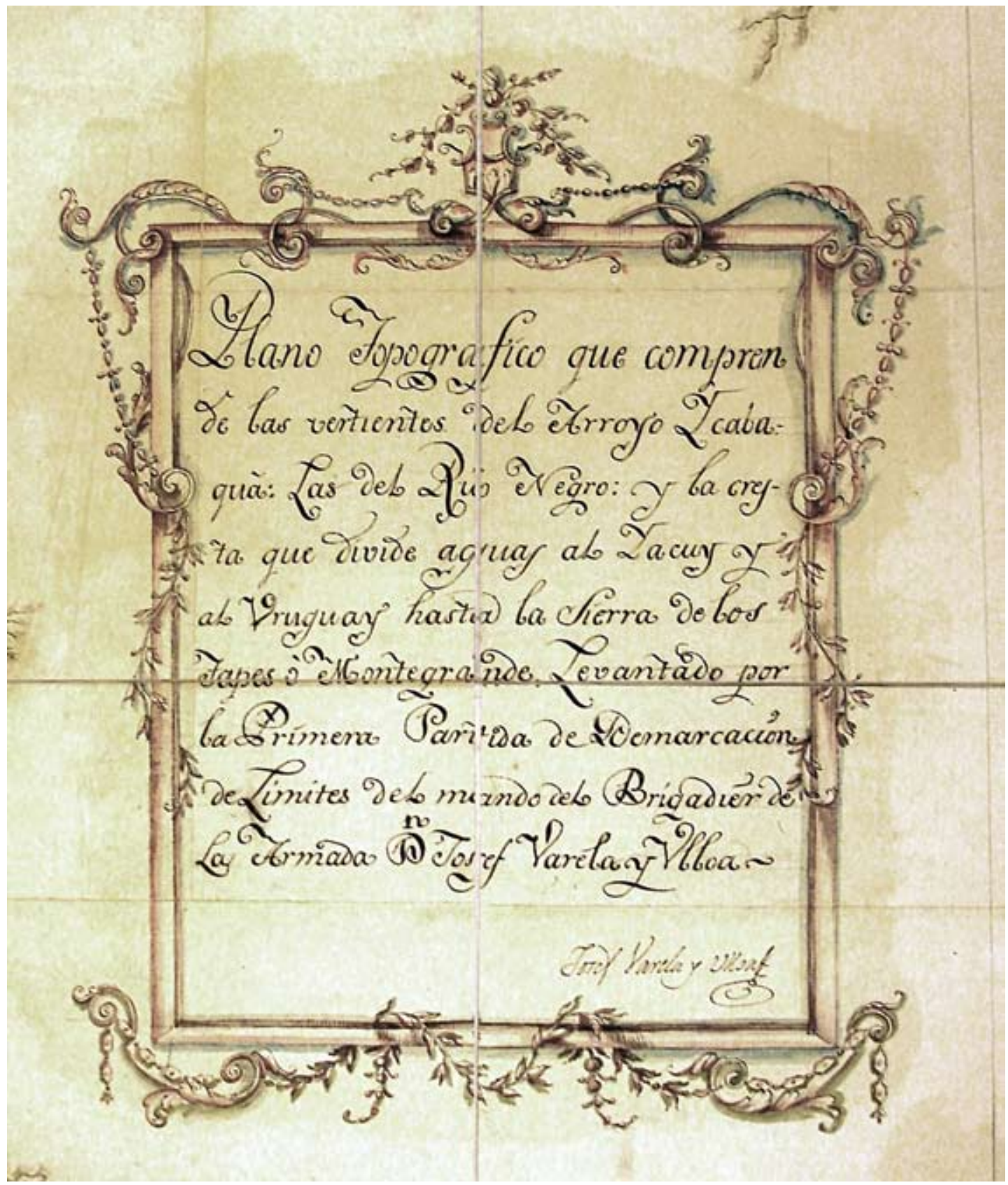

Figura 5 - Detalhe do mapa manuscrito preparado pelos demarcadores. Plano topográfico dos afluentes do rio Uruguai, concluído em 1788, preparada pelos demarcadores Jose Varela y Ulloa e Sebastião da Veiga Cabral. Biblioteca do Congresso, Washington (D.C.). 


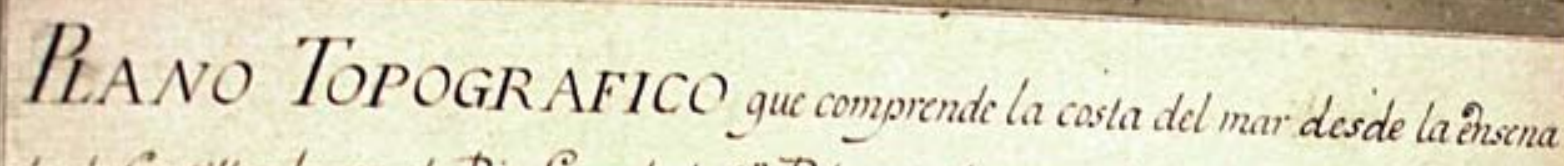

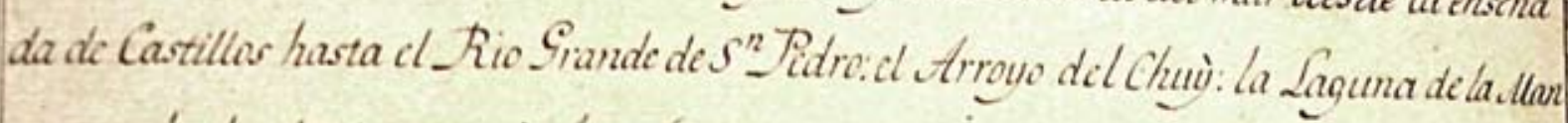

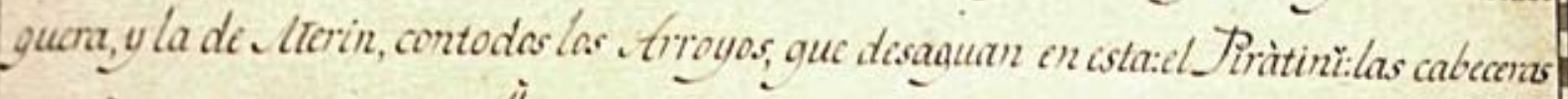

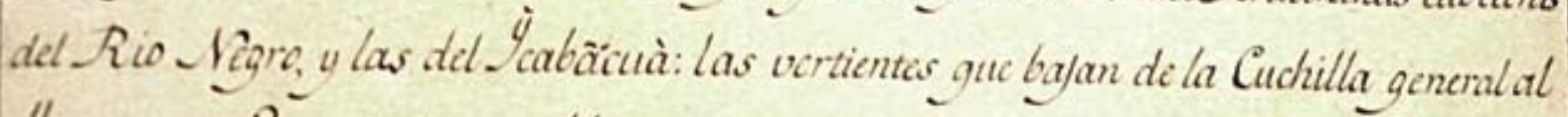

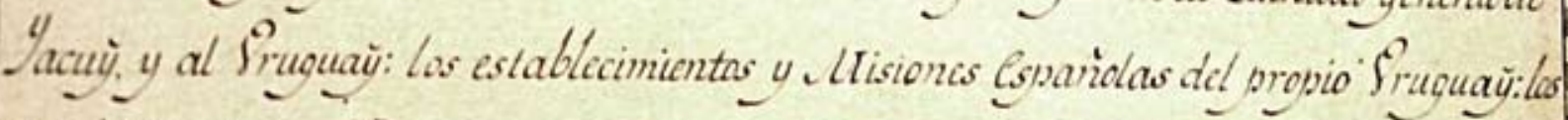
Cstablecimientos Portugueses mas inmediatos a dichas. Misiones:y el curso de una gran parte del Sruguai con la boca del Rio à oue los Demarcadores pasades die: ron al nombre de Toiri; cxorsandose en el mismo. Tlano los terrenas y a demaradas, y los gue cstan endisputa entre las Comisarias. Pinncipales de los dos Soberanos, por cuya

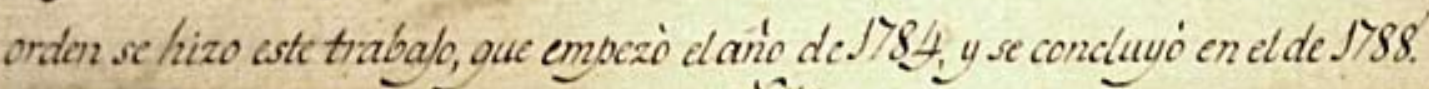

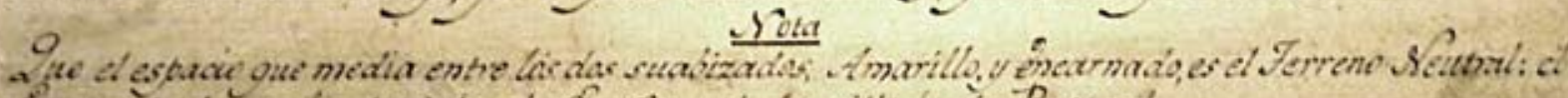

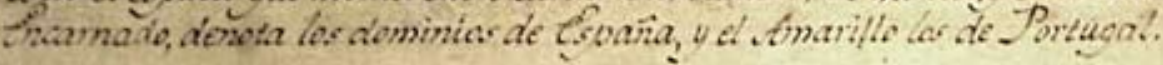

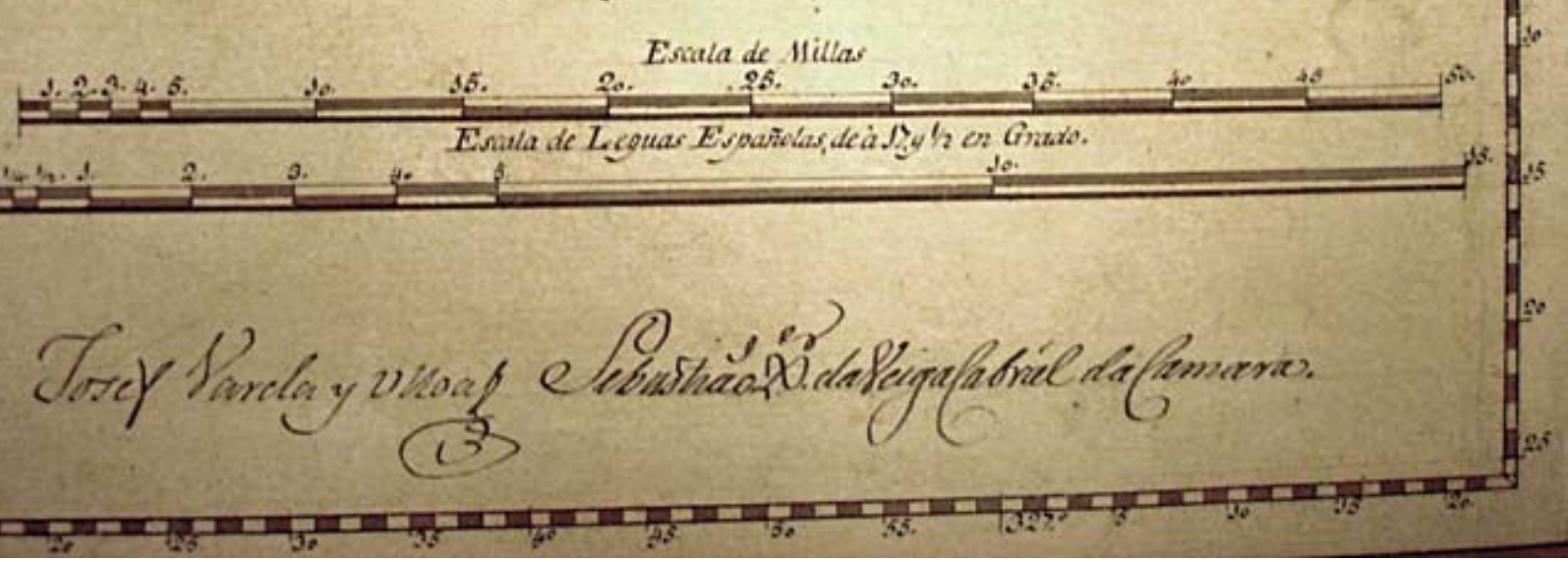

Figura 6 - Detalhe do mapa manuscrito preparado pelos demarcadores. Plano topográfico dos afluentes do rio Uruguai, concluído em 1788, preparada pelos demarcadores Jose Varela y Ulloa e Sebastião da Veiga Cabral. Biblioteca do Congresso, Washington (D.C.). 
26. Ver Carta de João Pereira Caldas enviada de Belém em 29 de julho de 1759. Arquivo do Estado de São Paulo. Manuscritos T. C. Avisos e Cartas Régias 1765-1777, Lata 62 , ordem 420 , livro 169 , fl. 14.

27. Cf. Agradeço as informações, cedidas pela historiadora e urbanista Maria Fernanda Dentl. Veja-se também o artigo de Beatriz P. Siqueira Bueno.

28. Cf. Renata Malcher Araújo (2000).

29. Cf. Luiz Felipe de Alencastro (1992); e Nadia Farage (1991, p. 100).

30. Cf. Bárbara Sommer (2000); e Patrícia Maria de Melo Sampaio (2001, capítulos 7-10).

31. A afirmação está no item 11 do Diretório dos índios. Apud Rita Heloisa de Almeida (1997).

32. Cf. Manuela Carneiro da Cunha $(1987$, p. 114) instruía que fossem de origem portuguesa os nomes de todas as vilas criadas. A nova toponímia urbana deveria ser um simulacro da metropolitana. $\bigcirc$ rebatismo do território era parte de uma política mais ampla de secularização da administração colonial, ensejada pelo consulado pombalino. Em correspondência, João Pereira Caldas, o governador da capitania do Piauí assegurou ao monarca que usaria a nomenclatura dos lugares e vilas do Reino de Portugal: "sem atenção aos nomes bárbaros que têm..."26.

D. Luis Antonio Botelho de Matos, governador da Capitania de São Paulo, também deu curso à política de renomeação das novas vilas criadas em sua gestão: Guaratuba, passou a Vila de São Luiz; Lages, Vila Nova dos Prazeres; Paraibuna, São Luiz e Santo Antonio de Paraíbuna; Jaguari, Vila de Bragança; Yapó, Vila de Castro27. Porém, mais definitivas foram as mudanças observadas nas regiões dos aldeamentos jesuíticos, onde Luis Pinto de Souza Coutinho, o visconde de Balsemão, atribuiu nomes lusitanos a todos aldeamentos missionários na região do Mato Grosso ${ }^{28}$

objetivo da coroa era constituir um instrumento de ocupação legal das fronteiras luso-espanholas no continente americano. Se, no plano internacional, a nova legislação transformava os índios em súditos do rei português - e, com isso, firmava o uti possidetis lusitano ${ }^{29}$-, no plano interno, a doação de terras (sesmarias) às novas vilas indígenas suscitava tensões e conflitos fundiários com os grandes fazendeiros e posseiros, que viram seus privilégios de ocupação "imemorial" das terras ameaçados pelas novas vilas indígenas ${ }^{30}$.

Além da atribuição dos nomes das principais vilas e cidades portuguesas às vilas indígenas, a transformação dos índios em súditos requeria também o aportuguesamento dos sobrenomes:

Terão daqui por diante todos os índios sobrenomes, havendo grande cuidado dos Diretores em Ihes introduzir os mesmos apelidos das famílias de Portugal; por ter moralmente certo, que tendo eles os mesmos apelidos, e sobrenomes, de que usam os brancos, e as mais pessoas que se acham civilizadas, cuidaram em procurar os meios mais lícitos e virtuosos de viverem, e se tratarem a sua imitação ${ }^{31}$.

A estratégia visava a reforçar a política de miscigenação entre as populações brancas pobres e os grupos indígenas. Os descendentes de portugueses eram estimulados a casar com indígenas através da concessão de privilégios como a isenção de dízimos. Por ironia do destino, o aportuguesamento dos sobrenomes serviria, 100 anos mais tarde, como pretexto à espoliação das terras atribuídas às sesmarias indígenas. Após a lei de terras, em 1850, as aldeias indígenas de Goiás, Ceará, Sergipe, Pernambuco e Rio de Janeiro foram declaradas extintas, sob alegação de ser sua população apenas mestiça ${ }^{32}$

Uma das medidas mais impressionantes foi a proibição do uso das línguas nativas e da "língua geral", com a correspondente exigência de que todos falassem português: "para desterrar este pernicioso abuso, será um dos principais 


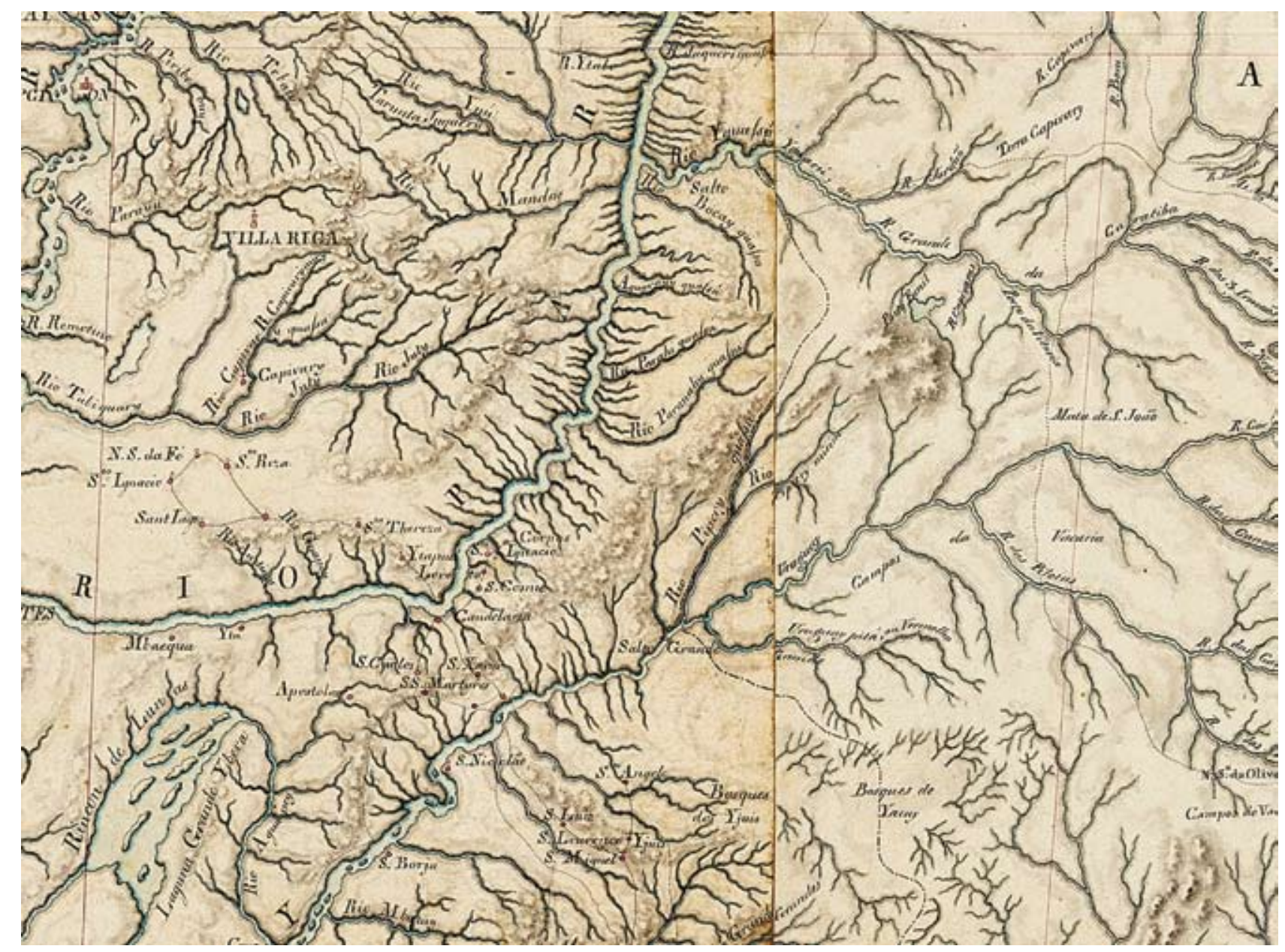

Figura 7 - Detalhe do rio Pipiriguaçu, no centro da imagem. [Carta Geral do Brasil], atribuída a José Joaquim Freire, [1797]. Arquivo Militar, Direcção dos Serviços de Engenharia, Lisboa.

dos diretores estabelecer nas suas respectivas vilas ou lugares o uso da língua portuguesa, não consentindo de modo algum, que os meninos e meninas, que pertencem as escolas, e todos aqueles índios, que forem capazes de instrução nesta matéria, usem das línguas próprias de suas nações, ou da chamada geral" 33 .

Resta, ainda, avaliar de que maneira as tentativas, promovidas pela reformas pombalinas, de erradicar as línguas nativas (especialmente a língua geral) incidiram substantivamente na produção cartográfica manuscrita e impressa. Os mapas produzidos nessa época constituíram mais um dos recursos para liquidação das jurisdições corporativas, conforme pretendia o consulado pombalino ${ }^{34}$. Dos aspectos mais visíveis do reformismo pombalino, a lusitanização dos topônimos foi só um dos que, ao fim e ao cabo, procurou afirmar novas modalidades de apropriação plena da propriedade fundiária ${ }^{35}$.
33. A afirmação está no item 6 do Diretório dos índios Apud Rita Heloisa de Almeida (1997); ver, ainda, Maria Helena Ochio Flexor (2001).

34. Ver Ana Cristina Nogueira da Silva (2003, p. 297 319).

35. Ver Márcia Menendes Motta (2006); Caio Prado Junior (1953). 


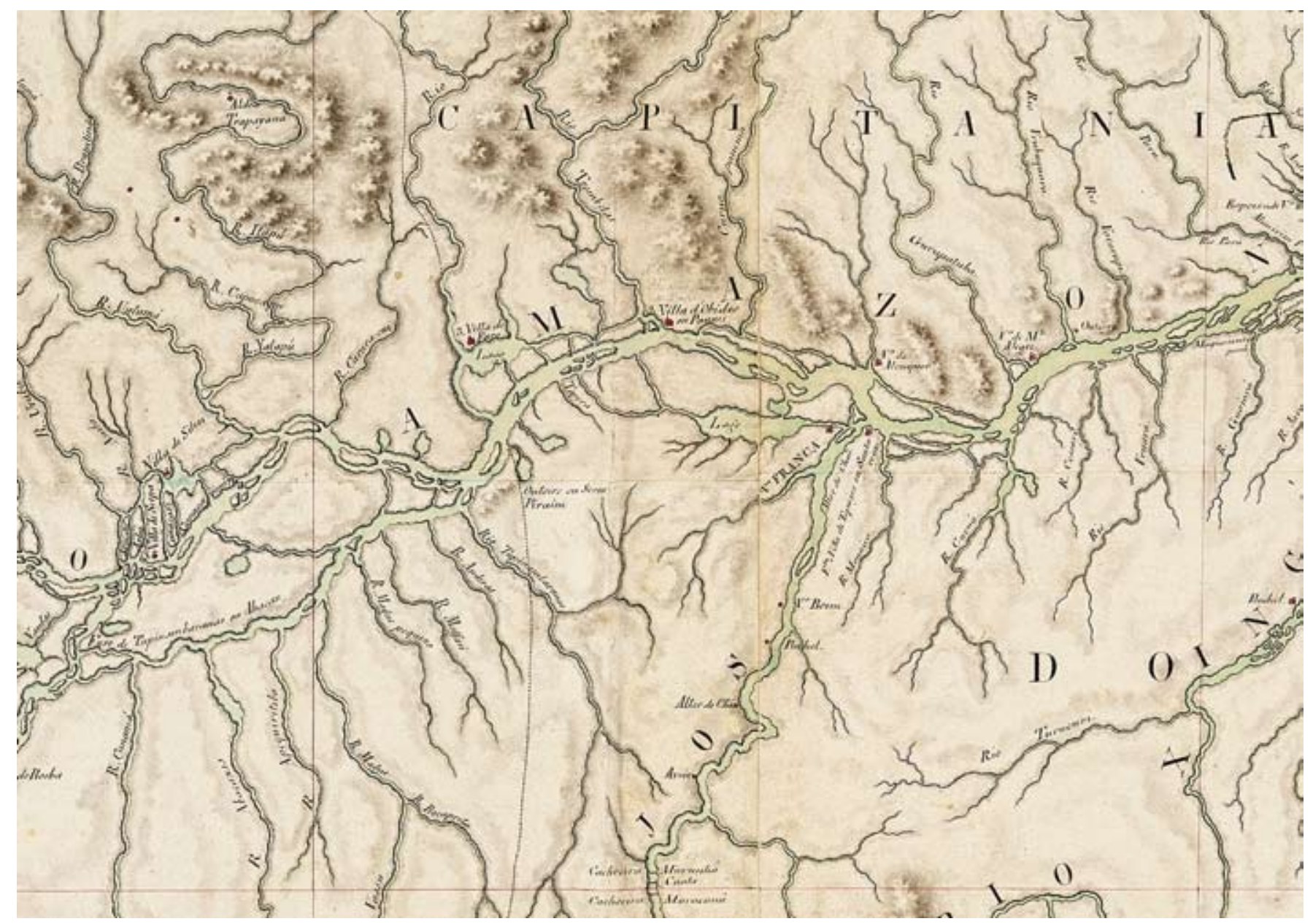

Figura 8 - Rede de vilas e fortificações construídas ao longo do rio Negro. Detalhe da [Carta Geral do Brasil], atribuída a José Joaquim Freire, [1797]. Arquivo Militar, Direcção dos Serviços de Engenharia, Lisboa. 


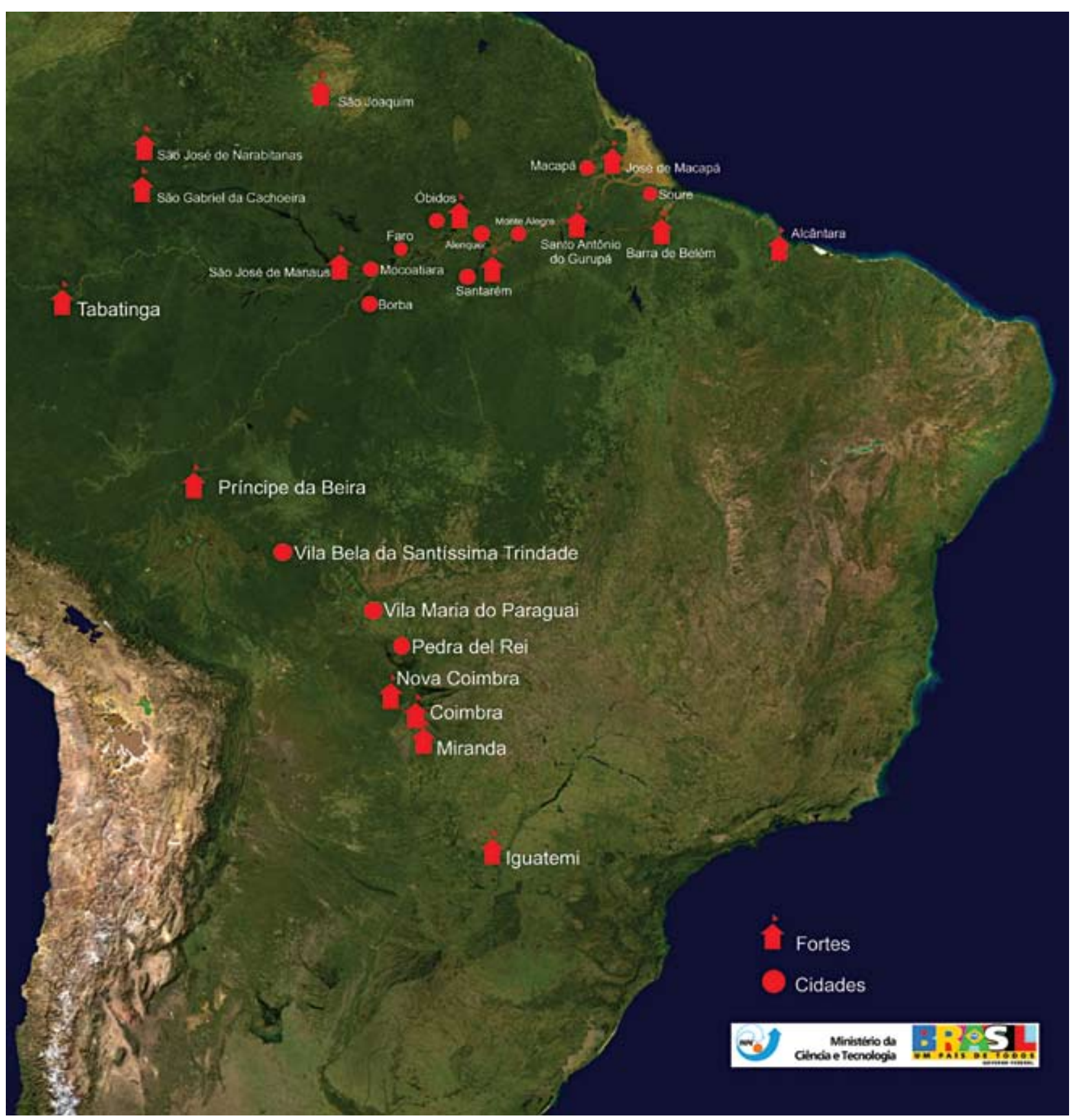

Figura 9 - Beatriz P. Siqueira Bueno, Iris Kantor e equipe do INPE, coordenada por Paulo Martini. Exercício de reconstituição em base de satélite da rede de fortificações do século XVIII no rio Negro, Amazônia. INPE - Instituto de Pesquisas Espaciais, São José dos Campos. 
36. Ver Antonio Vasconcelos de Saldanha (2001, p. $387-$ 440); Paulo Pedro Perides (1995); . Francisco Falcon (1982, p. 412-415); e, ainda, José Ribeiro Junior (1969).

37. Ver Sergio Buarque de Holanda (1962); Maria Odila Leite da Silva Dias (2005a). E, especialmente, os artigos recentes de Wilma Peres Costa e Cecília Helena de Salles Oliveira, publicados na revista eletrônica Almanack Braziliense, um dos desdobramentos do Projeto Temático Formação do Estado e da nação: Brasil (c.1780-1850), financiado pela Fapesp e sediado no Instituto de Estudos Brasileiros da Universidade de São Paulo, coordenado por István Jancsó.

38. Ver Marta Rosa Amoroso (1991).

39. Ver John M. Monteiro. (2001, capítulos 6-7).

40. Ver Rita Heloisa Almeida (2002).

41. Ver Fernanda Sposito (2006, p. 40-114).
Por outro lado, a política indigenista articulou-se com o processo de abolição das capitanias hereditárias e sua incorporação ao patrimônio da coroa em 1759. Consolidava-se, então, um novo princípio de uniformização das jurisdições territoriais sob controle direto da coroa portuguesa. Assim, eram redefinidas subordinações entre as capitanias centrais e periféricas ${ }^{36}$.

A reconstituição das práticas sociais de delimitação das fronteiras geográficas e de fixação da toponímica (em diferentes níveis: municipal, judiciária, capitania, bispado) leva-nos a explorar os dilemas vividos pela geração de cartógrafos e naturalistas que atuaram no espaço americano durante a passagem do século XVIII para o século XIX. Grande parte deles era originária do Brasi| ${ }^{37}$. Os conhecimentos adquiridos nas expedições demarcadoras e nas viagens filosóficas orientaram o assentamento das populações indígenas em vilas estrategicamente implantadas nas fronteiras sob lifígio com a França e a Espanha.

Paradoxalmente, esses integrantes das expedições demarcadoras e científicas seriam os mesmos homens que viriam a apoiar a revogação da legislação indigenista, movidos, sobretudo, pelas tensões fundiárias e pela dificuldade de administrar a mão-de-obra indígena sem a intermediação dos missionários. As dificuldades para regulamentar e demarcar as terras indígenas impediram a efetivação da nova legislação, levando à sua revogação através da Carta Régia de 1798.

Os relatos dos cartógrafos dessa época constroem uma visão negativa das possibilidades de civilização dos ameríndios, sobretudo no que toca à resistência indígena ao modelo de vida urbano e à disciplina do trabalho ${ }^{38}$. Mais do que nunca, nos diários dos demarcadores e naturalistas luso-americanos, a mão-de-obra indígena passava a ser associada a ociosidade, indolência e indisciplina (vide figuras 8, 9, 10 e 11 do artigo de Junia Furtado neste dossiê). Obviamente, por trás do debate intelectual sobre os modelos de aculturação civil do indígena, havia uma viva disputa pela exploração das terras, dos recursos naturais, e pelo modo de administrar a mão-de-obra nativa ${ }^{39}$.

A revogação da legislação pombalina aprofundou a desagregação das vilas indígenas. Desde então, instituiu-se, informalmente, uma espécie de código de trabalho compulsório. A nova lei de 1798 extinguiu as sesmarias indígenas, colocando-as à venda. Os índios que não tivessem casa e roça para cuidar poderiam ser recrutados, por autoridades ou por particulares, passando a ser considerados como órfãos perante a lei, tutelados pelos ouvidores e juízes de paz ${ }^{40}$.

A vinda da Corte e o processo de elevação da colônia ao estatuto de Reino Unido de Portugal, Brasil e Algarves (1815) demarcam o refluxo das políticas de lusitanização da toponímia e o "ressurgimento" dos topônimos nativos. Apesar de seu nativismo americanista, a geração que conduziu a emancipação política do Brasil também esteve envolvida no restabelecimento da Guerra Justa - e cativeiro dos grupos indígenas hostis, como os botocudos, dos sertões de Minas, Espírito Santo e Bahia, ou os bugres de São Paulo - em Carta Régia decreto de $1808^{41}$.

O Ato adicional, em 1834, incumbiu as assembleias legislativas 
provinciais, cumulativamente com o Governo Geral, de legislar sobre a catequese e a civilização dos índios. Até então, as províncias propunham leis e decretos que tinham de ser sancionados pela Assembleia e pelo imperador. Mas somente em 1845 seria definida nova política global para todo o Império brasileiro ${ }^{42}$. Até essa data, o destino das populações indígenas dependeu das negociações entre as elites regionais e o governo central. A deslusitanização dos topônimos coincidiu, portanto, com o processo de expansão interna da fronteira colonial, expansão essa promovida pelas elites regionais ${ }^{43}$. É flagrante a erradicação dos etnônimos indígenas nas cartas geográficas do período pós colonial em comparação com os períodos anteriores. Nas cartas do Império do Brasil a indicação da localização dos povos indígenas é substituída por designações genéricas líndios bravos; sertão do gentio) ou por espaços em branco. Muito embora, o uso de vocábulos indígenas tenha se intensificado.

Se a cartografia oficial, representada pela Carta Geral do Brasil preparada por Antonio Pires da Silva Pontes (1798) - expressa a política de re-semantização do espaço reivindicado pelos portugueses nas cortes internacionais; em contraponto, o atlas Guia dos Caminhantes, copiado e pintado por Anastácio de Sant'Anna, indica uma diferença significativa no modo de apreender e descrever o espaço vivido pelas elites locais como se poderá observar no uso intensivo do topônimos e informações sobre as populações indigenas (Figuras 10-12).
42. Ver Luiz Felipe de Alencastro (v. 2, 1986, p. 369417).

43. Cf. Antonio Carlos Robert de Moraes (2007).

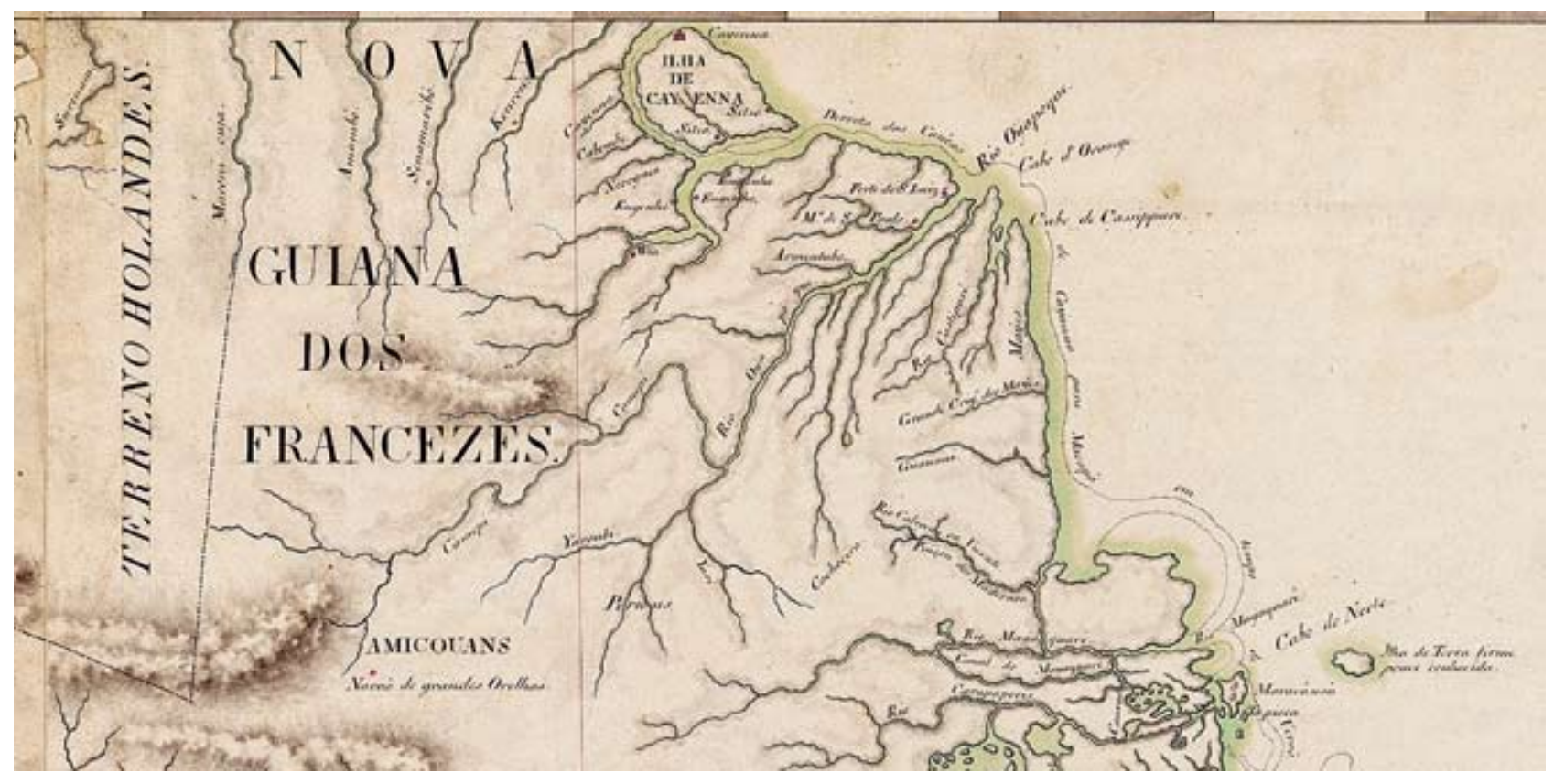

Figura 10 - Detalhe das Guianas Francesas. [Carta Geral do Brasil], atribuída a José Joaquim Freire, [1797]. Arquivo Militar, Direcção dos Serviços de Engenharia, Lisboa. 


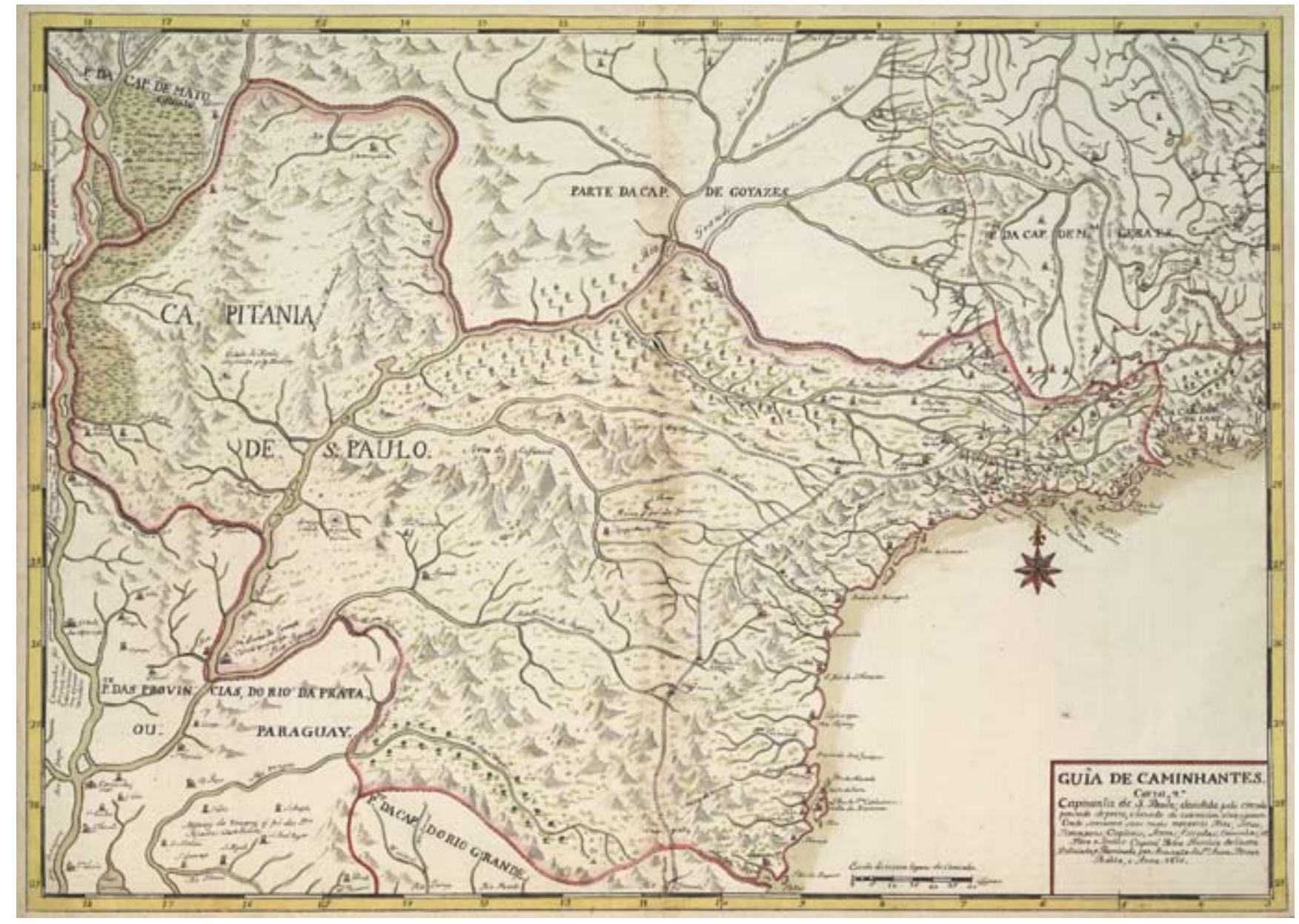

Figura 11 - Mapa da Capitania de São Paulo e adjacências. Anastácio de Sant'Anna. Guia dos Caminhantes [Capitania de São Paulo], 1816. Acervo da Fundação Biblioteca Nacional, Rio de Janeiro.

44. Cf. Maria Odila Leite da Silva Dias (2005b). atlas Guia dos Caminhantes é composto de 14 pranchas aquareladas que abrangem as 13 capitanias da América portuguesa em 1816 . Essa documentação nos oferece uma perspectiva diferenciada da obra cartográfica realizada pelos engenheiros militares. Auto-referido como "o pardo velho", Anastácio de Sant'Anna justifica a necessidade de fazer um novo atlas para suprimir os "erros" difundidos pelos mapas impressos e roteiros preparados pos "homens de sciência". Curiosamente, dedica seu labor aos comerciantes, fazendeiros e feitores, fazendo, inclusive, uma série de recomendações aos jovens, naturais da América, em nítido tom patriótico. Essas representações evidenciam tensões inerentes ao processo de construção da hegemonia da Corte portuguesa instalada no Rio de Janeiro 44.

Paradoxalmente, a presença da Corte representou também uma tendência para a recuperação da toponímia nativa, como parte do processo de 


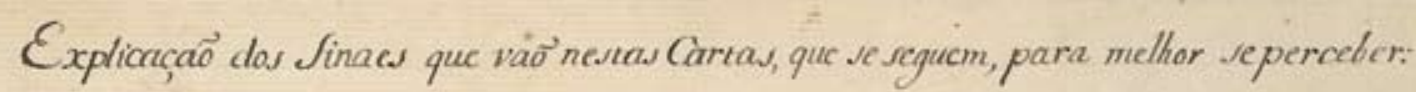

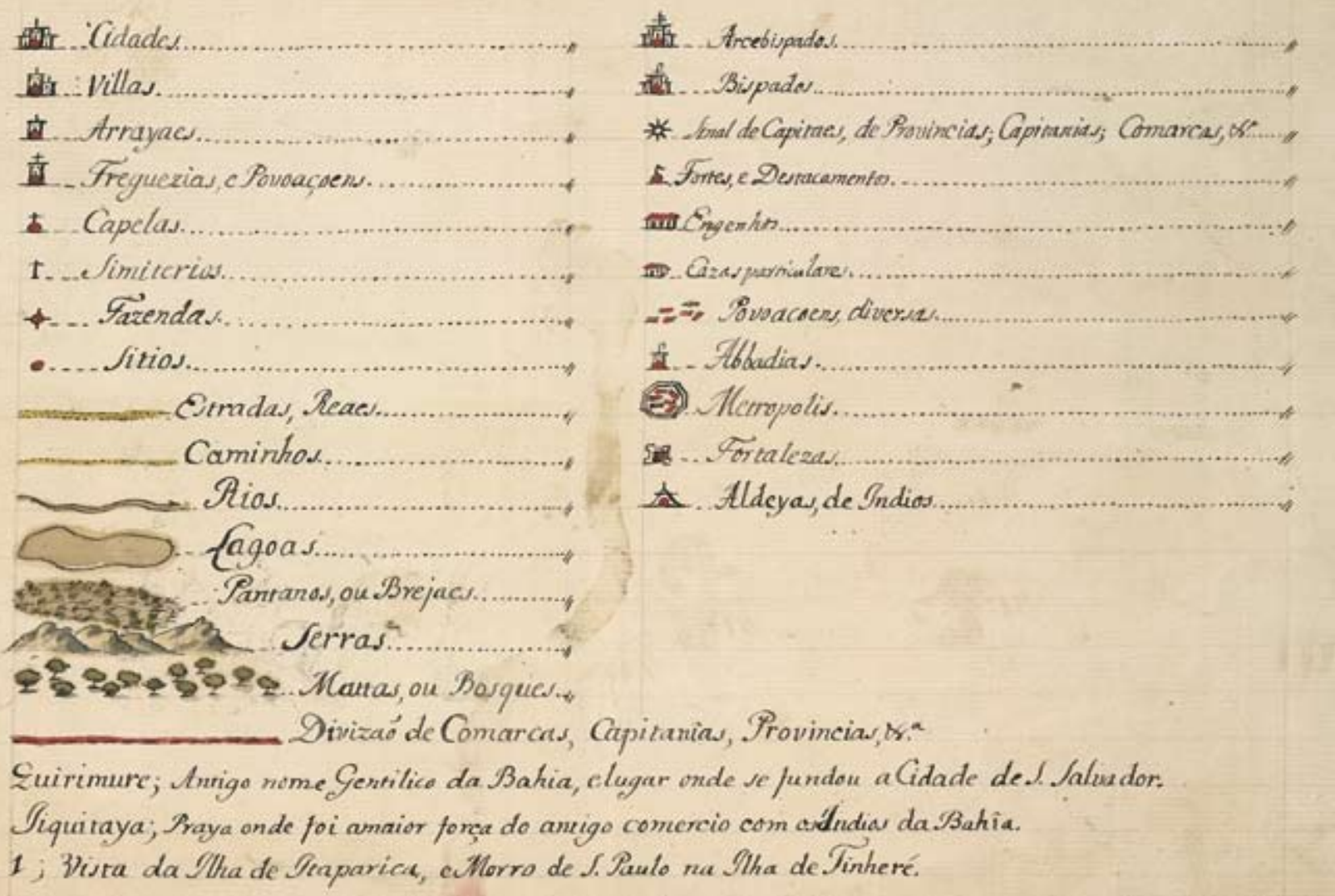

Figura 12 - Detalhe da legenda, com indicações da toponímia indígena. Anastácio de Sant'Anna. Guia dos Caminhantes [Capitania de São Paulo], 1816. Acervo da Fundação Biblioteca Nacional, Rio de Janeiro.

americanização da Monarquia portuguesa. A tupinização dos sobrenomes, dos títulos maçônicos foi um fenômeno correlato ao resgate da toponímia indígena pelas mesmas elites que estavam silenciando os etnônimos indígenas nas cartas geográficas ${ }^{45}$. No entanto, a exaltação do indígena - como antepassado da nacionalidade e guardião da terra - tomaria corpo com o movimento romântico deflagrado a partir da década de 1840, que, aliás, seguiu o compasso dos debates parlamentares sobre o fim do tráfico negreiro e sobre as políticas fundiária e imigratória. Com efeito, como tentei mostrar, a re-emergência da toponímia indígena foi simultânea ao aprofundamento das práticas de exclusão das populações indígenas e africanas ${ }^{46}$.

Na década de 1840, quando o visconde de Santarém publicava seus estudos, iniciava-se a era dos contenciosos fronteiriços entre o Império do Brasil e os demais poderes coloniais - ingleses, franceses e holandeses - especialmente
45. Cf. Luiz Felipe de Alencastro (1997, p. 54).

46. Cf. John M. Monteiro (2001, especialmente capítu$\operatorname{los}$ 6-7) 
na região amazônica... Os trabalhos de Santarém foram rapidamente assimilados pela diplomacia brasileira na disputa com a França pela fronteira no cabo do Norte. A diplomacia brasileira valeu-se das evidências toponímicas registradas no mapas produzidos durante a colonização. Nesse contencioso, a hidrotoponímia foi fundamental para a definição dos limites territoriais. $\bigcirc$ litígio originou-se da transposição de nomes de rios limítrofes. $\bigcirc$ problema consistia na determinação do verdadeiro Oiapoque, confundido com o Amazonas/Maranhão pelos cartógrafos franceses, para os quais havia dois rios: o Oyapoc e o Wiapoc (Figura 10). A diplomacia - do Império e a da República - mobilizou a memória cartográfica para obtenção dos seus pleitos nos tribunais internacionais, embora só muito recentemente as prerrogativas históricas das populações indígenas tenham começado a ser levadas em conta.

\section{REFERÊNCIAS}

\section{FONTES}

ALMEIDA, Rita Heloisa. A Carta Régia de 12 de maio de 1798 e outros documentos sobre índios no Códice 807. Revista do Instituto Histórico e Geográfico Brasileiro, Rio de Janeiro, n. 416, p. 171-204, 2002.

CORTESÃO, Jaime. Antecedentes do Tratado [de Madri]. Rio de Janeiro: Instituto Rio Branco, [s. d.].

FREITAS, Serafim de. Do justo império asiático dos portugueses. Lisboa: Instituto de Alta Cultura, 1959.

GROUTIUS, Hugo. Do Direito da Paz e da Guerra. Trad. Ciro Mioranza. Ijuí: Editora da Unijuí, 2004.

SANCHES, Antonio Nunes Ribeiro. Dificuldades que tem um reino velho para emendar-se e outros textos, Victor SÁ (compilador), Livros Horizontes, 1980, p.138.

SANTARÉM, 20 visconde de (Manuel Francisco Leitão e Carvalhosa). Memória sobre a prioridade dos descobrimentos portugueses na costa d África ocidental para servir de ilustração à chronica da Conquista da Guiné por Azurara (Paris, 1841), Lisboa: Comissão Executiva das Comemorações do Quinto Centenário da Morte do Infante D. Henrique, 1958, p. 84.

\section{LIVROS E PERIÓDICOS}

ALBUQUERQUE, Martim de. Prefácio In: SANTARÉM, 2o visconde de (Manuel Francisco Leitão e Carvalhosa). Recherches sur la priorité de la découverte des pays situés sur la côte occidentale d'Afrique: au dela du Cap Bojador, et essai sur l'histoire de la cosmografphie et de la cartographie pendant le moyen-age. Porto: Administração Municipal do Porto; INAPA, 1989.

ADONIAS, Isa. Mapa: Imagens da formação territorial brasileira. Rio de Janeiro: Fundação Emílio Odebrecht, 1993. 
ALENCASTRO, Luiz Felipe de. Le commerce des vivants: traite d'esclaves et pax lusitana dans l'atlantique sud, 2. Paris: Université de Paris X, 1986.

ALENCASTRO, Luiz Felipe de. Interação europeia com as sociedades brasileiras. In: PAULINO, Francisco Faria (Org.). Brasil: nas vésperas do mundo moderno. Lisboa: Comissão Nacional para os Descobrimentos Portugueses, 1992. p. 97-119.

ALENCASTRO, Luiz Felipe de. História da vida privada no Brasil, 2. São Paulo: Companhia das Letras, 1997.

ALMEIDA, André Ferrand de. A formação do espaço brasileiro e o projeto do Novo atlas da América portuguesa (1713-1748). Lisboa: Comissão Nacional para os Descobrimentos Portugueses, 2001.

ALMEIRA, Rita Heloisa de. O Diretório dos Índios: um projeto de civilização no Brasil do século XVIII. Brasília: Editora da UNB, 1997.

AMOROSO, Marta Rosa. Guerra Mura no século XVIII: versos e versões. Representações dos Mura no Imaginário Colonial. 1991. Dissertação (Mestrado em Antropologia) - Instituto de Filosofia e Ciências Humanas da Universidade de Campinas, Campinas, 1991.

ARAUJO, Renata Malcher. As cidades da Amazônia no século XVIII: Belém, Macapá e Mazagão. 1992. Dissertação (Mestrado em Urbanismo) - Faculdade de Arquitetura da Universidade do Porto, Porto, 1992.

A urbanização do Mato Grosso no século XVIII. 2000. Tese (Doutorado em História da Arte) -Lisboa, 2000.

BUENO, Beatriz P. Siqueira. Desenho e desígnio: o Brasil dos engenheiros militares (1500-1822). 2001. Tese (Doutorado) - Faculdade de Arquitetura e Urbanismo, Universidade de São Paulo, São Paulo, 2001 (consultar versão revisada em 2003).

CAPEL, Horacio. Geografía e Cartografía. In: SELLÉS, Manuel et al. Carlos III: la ciencia de la ilustración. Madrid: Alianza, 1988. p. 99-126.

CIMBALISTA,Renato. Relíquias sagradas e a construção do território cristão na Idade Moderna. Anais do Museu Paulista, São Paulo, v.14, n. 2, p. 11-50, 2006.

COELHO, Mauro Cezar. Do sertão para o mar: um estudo sobre a experiência portuguesa na América, a partir da Colônia: o caso do Diretório dos Índios (1751-1798). 2005. Tese (Doutorado em História), Faculdade de Filosofia, Letras e Ciências Humanas da Universidade de São Paulo, São Paulo, 2005.

CORTESÃO, Jaime. Alexandre de Gusmão e o Tratado de Madrid. Lisboa: Horizonte, 1984.

CUNHA, Manuela Carneiro da. Antropologia do Brasil. São Paulo: Brasiliense, 1987.

DIAS, Maria Odila Leite da Silva. Aspectos da Ilustração no Brasil [1968]. In: A interiorização da metrópole e outros estudos. São Paulo: Alameda, 2005a.

. A interiorização da metrópole [1972]. In: A interiorização da metrópole e outros estudos. São Paulo: Alameda, 2005b. 
DICK, Maria Vicentina de Paula do Amaral. A motivação toponímica e a realidade brasileira. São Paulo: Arquivo do Estado, 1990.

DOMINGUES, Ângela. Quando os índios eram vassalos: colonização e relações de poder no Norte do Brasil na segunda metade do século XVIII. Lisboa: Comissão Nacional para os Descobrimentos Portugueses, 2000.

ELLIOT, John. Empires of the Atlantic world: Britain and Spain in America, 1492-1830. New Haven: Yale University Press, 2006.

FALCON, Francisco. A época pombalina. São Paulo: Ática, 1982.

FARAGE, Nadia. As muralhas dos sertões: os povos indígenas no Rio Branco e a colonização. Rio de Janeiro: Paz e Terra; Anpocs, 1991.

FLEXOR, Maria Helena Ochi. Aprender a ler, escrever e contar no Brasil do século XVIII. Filosofia e Linguística, São Paulo, v. 4, p. 91-157, 2001.

GARCIA, João Carlos. Mapas e Atlas do Visconde de Santarém: a prioridade no descobrimento da África Ocidental. Catálogo da Exposição cartobibliográfica. Lisboa: Biblioteca Nacional, 2006.

GESTEIRA, Heloisa Meireles. Da Liberdade dos mares: Hugo Grotius e a soberania do Imperium. In: MUNTEAL FILHO, Oswaldo et al. Olhares sobre o político. Rio de Janeiro: Editora da Universidade Estadual do Rio de Janeiro, 2002. p. 175-190.

HARLEY, J. B. La Nueva Naturaleza de los Mapas. Trad. Letícia Garcia Cortes; Juan Carlos Rodriguez. Ciudad de México: Fondo de Cultura do México, 2005.

HESPANHA, Antonio Manuel. Introdução. In: GROUTIUS, Hugo. Do Direito da Paz e da Guerra. Trad. Ciro Mioranza. Ijuí: Editora da Unijuí, 2004. p. 15-27.

HOLANDA, Sergio Buarque de. Herança colonial: sua desagregação. In: História geral da civilização brasileira: o Brasil monárquico, 1. São Paulo: Difel, 1962. p. 9-39.

Visão do Paraíso: os motivos edênicos no descobrimento e colonização do Brasil. $4^{\mathrm{a}}$ ed. São Paulo: Nacional, 1985.

KANTOR, Íris. Esquecidos e Renascidos: a bistoriografia acadêmica luso-americana. São Paulo: Hucitec, 2004.

MONTEIRO, John M. Tupis, tapuias e historiadores. Estudos de história indígena e indigenismo. Tese (Livre-docência em Antropologia) - Instituto de Filosofia e Ciências Humanas da Universidade de Campinas, Campinas, 2001.

MORAES, Antonio Carlos Robert de. Território, região e formação colonial: apontamentos em torno da geografia histórica da independência brasileira. In: INSTITUTO MORA. La Integración del territorio en una idea de Estado. México e Brasil. Cidade do México: Instituto Mora; Universidad Nacional de México, 2007. p. 497-506.

MOTTA, Márcia Menendes. Francisco Mauricio de Souza Coutinho: Sesmarias e os limites do Poder. In: VAINFAS, Ronaldo et al. Retratos do Império. Niterói: EdUFF, 2006. p. 351-368.

NICOLET, Claude. L'inventaire $d u$ monde: géographie et politique aux origenes de l'empire romanin, Paris: Hachette, 1988. 
NORDMAN, Daniel. Les titres et les preuves. La notion de droits historique en France (1648-1661). In: BÉLY, Lucien. L'Europe des traités de Westphalie. Paris: Presses Universitaires Françaises, 2000. p. 246-252.

PADGEN, Anthony. Commerce and Conquest: Hugo Grotius and Serafim de Freitas on the freedom of the sea. Mare Liberum, Lisboa, v. 20, p. 33-55, 2000.

PERIDES, Paulo Pedro. A organização político administrativa e o processo de regionalização do território colonial brasileiro. Revista do Departamento de Geografia, São Paulo, n. 9, p. 77-91. 1995.

PRADO JUNIOR, Caio. Formação do Brasil contemporâneo. 4. ed. São Paulo: Brasiliense, 1953.

RESENDE, Maria Leônia Chaves de. Gentios brasílicos: índios coloniais em Minas Gerais setecentista. 2003. Tese (Doutorado em História) - Instituto de Filosofia e Ciências Humanas da Universidade de Campinas, Campinas, 2003.

RIBEIRO JUNIOR, José. Extrato da legislação para o Brasil durante o reinado de D. José I (1750-1777). Anais de História, Assis, v. 1, p. 77-129, 1968-1969.

SAFIER, Neil. Measuring the new world: Englightenment science and South América. Chicago: The University of Chicago Press, 2008. p. 57-92.

SALDANHA, Antonio Vasconcelos de. As capitanias do Brasil: antecedentes, desenvolvimento e extinção de um fenômeno atlântico. Lisboa: Comissão Nacional para os Descobrimentos Portugueses, 2001.

SAMPAIO, Patrícia Maria de Melo. Espelhos Partidos: etnia, legislação e desigualdade na Colônia. Sertões do Grão-Pará (c. 1755-c. 1823). 2001. Tese (Doutorado em História) - Universidade Federal Fluminense, Niterói, 2001.

SAMPAIO, Teodoro. O tupi na geografia nacional. 5. ed. São Paulo: Nacional 1987.

SEED, Patricia. Cerimoniais de posse na conquista europeia do Novo Mundo. Trad. Lenita Esteves. São Paulo: Unesp, 1999.

SILVA, Ana Cristina Nogueira da. Tradição e reforma na organização político-administrativa do espaço, Portugal, finais do século XVIII. In: JANCSÒ, IIstván. Brasil: Formação do Estado e da Nação, São Paulo: Hucitec, 2003. p. 297-319.

SILVA, Andrée Mansuy Diniz (Org.). Introdução. In: D. Rodrigo de Souza Coutinbo: textos políticos, econômicos e financeiros (1783-1811). Lisboa: Banco de Portugal, 1993.

SOMMER,Bárbara. Negotiated settlements: native Amazonians and Portuguese policy in Pará 1758-1798. 2000. Tese (Doutorado em História) - University of New Mexico, Albuquerque, 2000.

SPOSITO, Fernanda. Nem cidadãos, nem brasileiros: indígenas na formação do Estado Nacional e conflitos na província de São Paulo. 2006. Dissertação (Mestrado em História) - Faculdade de Filosofia Letras e Ciências Humanas da Universidade de São Paulo, São Paulo, 2006.

Artigo apresentado em 8/2008. Aprovado em 3/2009.

Annals of Museu Paulista. v. 17. n.2. July - Dec. 2009. 